\title{
PARADIGMA BARU PENGEMBANGAN WAKAF PRODUKTIF (Kajian Empiris Badan Wakaf Indonesia Propinsi Bangka Belitung)
}

\author{
Wulpiah \\ IAIN Syaikh Abdurrahman Siddik Bangka Belitung \\ Email: ulpiah2018@gmail.com
}

\begin{abstract}
At present the study and concern of the muslim community is being focused on socializing, utilizing and developing waqf, especially productive waqf. Which is one of the instrument of sharia social finance. Event the existence of productive endowments is very potential which is allegedly one of the complentary instrument solution for development financing.

There are many form of development and utilization of productive waqt in Indonesia both in the fields of agriculture plantations, economics such as establishment of sharia hotel, health; establishment of hospital, infrastructure and other business centers. Cash waqf which is one element of productive endowment can be alternative way of "expansion" of development and development of Islamic economic which can ultimately strengthen financial system stability.

The focus this paper will be "reading" the direction of development of productive waqf carried out by BWI Bangka Belitung regarding of socializing, education and implementation program. Therefore, "built in" the new paradigm of productive waqf so that its management its carried out professionally must continue to be encouraged. Furthermore, the intended paradigm is increasing capacity of nadzir; besides having religious knowledge and trust and also having enterpreneursip spriit. Bisides that BWI Bangka Belitung must start introducing cash waqf.
\end{abstract}

Keywords: paradigm, development and productive waqf

\begin{abstract}
Abstrak
Saat ini kajian dan concern masyarakat muslim sedang tertuju pada sosialisasi, pemanfaatan dan pengembangan wakaf, khususnya wakaf produktif yang merupakan salah satu intrumen keuangan sosial syariah. Bahkan eksistensi wakaf produktif sangat potensial ini disinyalir sebagai salah satu solusi instrumen pelengkap pembiayaan pembangunan.

Ada banyak bentuk pengembangan dan pemanfaatan wakaf produktif di Indonesia baik pada bidang pertanian dan perkebunan, ekonomi seperti pendirian hotel syariah, kesehatan; pendirian rumah sakit, dan infrastruktur dan sentra
\end{abstract}


usaha lainnya. Wakaf tunai yang merupakan salah satu unsur wakaf produktif idealnya dapat menjadi alternatif cara "ekspansi"pembangunan dan pengembangan ekonomi syariah yang pada akhirnya dapat memperkuat stabilitas sistem keuangan nasional.

Fokus tulisan ini akan "membaca" arah pengembangan wakaf produktif yang dilakukan oleh BWI Bangka Belitung terkait sosialisasi, edukasi dan implementasi programnya. Oleh karena itu mem"built in" paradigma baru wakaf produktif agar pengelolaannya dilakukan secara profesional harus terus digalakkan. Selanjutnya paradigma dimaksud adalah peningkatan kapasitas nadzir disamping memiliki ilmu agama dan amanah juga harus memiliki jiwa entrepreneurship; selain itu BWI harus memulai memperkenalkan wakaf tunai kepada masyarakat.

Kata-kata Kunci: Paradigma, Pengembangan dan Wakaf Produktif

\section{A. Pendahuluan}

Wakaf merupakan salah satu instrumen lembaga keuangan syariah yang berperan dalam pemberdayaan ekonomi, sosialkemasyarakatan umat. Secara historis, eksistensi lembaga wakaf sangat potensial dan strategis dalam membiayai berbagai kegiatan agama (Islam), pendidikan, kesehatan, pertanian, manufaktur dan lain-lain. Wakaf merupakan aspek ajaran Islam yang berdimensi spiritual-vertikal dan ajaran yang menekankan pentingnya kesejahteraan ekonomi berdimensi sosial-horizontal. Oleh karena itu perlu dilakukan reinterpretasi terhadap pemaknaan wakaf dan pemberdayaan harta wakaf agar memiliki makna yang lebih relevan dengan kondisi zaman serta urgen guna merumuskan desain pemberdayaan harta wakaf agar lebih optimal sehingga peningkatan kesejahteraan umat dapat dilakukan yang pada gilirannya memperkuat stabilitas sistem keuangan nasional.

Lahirnya Undang-Undang Republik Indonesia No. 41 Tahun 2004 tentang Wakaf diarahkan untuk memberdayakan wakaf dalam membangun kehidupan sosial ekonomi umat Islam. Kehadiran Undangundang wakaf ini menjadi momentum pemberdayaan wakaf secara produktif, sebab di dalamnya terkandung pemahaman yang komprehensif 
dan pola manajemen pemberdayaan potensi wakaf secara modern. Mengingat Indonesia sebagai negara berpenduduk muslim terbesar di dunia, wakaf merupakan salah satu potensi yang dapat dimanfaatkan untuk menciptakan keadilan sosial dengan tujuan mewujudkan kesejahteraan umat dan mengentaskan kemiskinan.

Sebab potret pengelolaan alokasi dana wakaf di Indonesia hari ini, yang belum mengarah pada pemberdayaan ekonomi umat dan cenderung hanya untuk kepentingan ibadah khusus dapat dimaklumi, karena memang pada umumnya ada keterbatasan umat Islam terkait pemahaman wakaf, baik mengenai harta yang diwakafkan maupun peruntukannya. Oleh sebab itu pengembangan wakaf produktif saat ini dibutuhkan untuk mendorong perekonomian nasional.

Tulisan ini mencoba mendeskripsikan pelaksanaan dan pengelolaan wakaf terkait optimalisasi peran Badan Wakaf Indonesia Bangka Belitung sebagai upaya pemberdayaan ekonomi umat, sehingga dapat dijadikan mekanisme guna mengentaskan kemiskinan dan media intermediasi dengan lembaga BAZNAS dalam memetakan persoalan umat sekaligus menemukan solusinya. BWI Bangka Belitung merupakan lembaga wakaf yang masih tergolong baru, ketika berbicara implementasi dan program pemberdayaan harta wakaf agar bersifat produktif, maka eksistensinya masih pada tataran sosialisasi lembaga dan program. Namun guna mengoptimalisasi gagasan BWI Bangka Belitung, maka sharing idea perlu dilakukan.

\section{B. Telaah Pustaka}

Ada beberapa tulisan dan hasil penelitian yang memiliki linkage dengan tulisan ini, antara lain: 
Pertama, hasil kajian Abdul Hakim ${ }^{1}$ menjelaskan wakaf menjadi solusi bagi pengembangan harta produktif dan sebagai bentuk kepedulian terhadap umat serta generasi yang akan datang. Mengingat wakaf sebagai salah satu kegiatan sosial sehingga dapat memacu pertumbuhan ekonomi, terkait dengan manajemen wakaf produktif yang diinginkan baik secara konseptual maupun sistem operasionalnya, hal ini diarahkan agar harta maupun tujuan, hendaknya dapat merealisasikan: Pertama, melalui terbentuknya yayasan yang dikelola oleh pihak swasta setempat dan tidak mengorbankan syarat mereka dalam mengelola wakaf, baik itu disebutkan secara terang-terangan dalam akte wakaf ataupun secara isyarat dari karakteristik kegiatan wakaf dan periode sejarah yang tumbuh. Kedua, eksistensi wakaf produktif, adalah meningkatkan kelayakan produksi dengan memperbesar hasil wakaf dan menekan pengeluaran administrasi dan investasi, melindungi pokok harta wakaf, serta mengurangi kerusakan dalam administrasi dan distribusi hasil-hasilnya. Aspek minimnya representasi kelayakan kepengurusan dari unsur pemerintah pada umumnya dapat dipertimbangka dalam investasi harta wakaf yang bertujuan meningkatkan keuntungan.

Kedua, Abdurrahman Kasdi² menjelaskan terdapat dua pola pengembangan hasil harta wakaf produktif yang dapat dilakukan oleh pengelola yaitu: pertama, pengembangan wakaf untuk kegiatan sosial, kesejahteraan umat, pengembangan pendidikan, sarana kesehatan, advokasi, kebijakan public, bantuan hukum, HAM, perlindungan anak, pelestarian lingkungan, pemberdayaan perempuan, seni dan budaya dan sebagainya. Kedua, pengembangan yang bernilai ekonomi, seperti

1 Abdul Hakim, Manajemen Harta Wakaf Produktif dan Investasi dalam Sistem Ekonomi Syariah, Jurnal Riptek, Vol. 4, Nomor II, Tahun 2010, hlm 28

${ }^{2}$ Abdurrahman Kasdi, Model Pemberdayaan Wakaf Produktif Di Indonesia, ZISWAF, Vol. 1, No. 1 Juni 2014, hal. 109 
mengembangkan perdagangan, investasi keuangan, mengembangkan asset industri, pembelian properti dan sebagainya.

Ketiga, Muhamad Anis $^{3}$ menjelaskan urgennya wakaf goes to campus sebagai upaya mengkaji animo citivitas academica, sebab kemajuan ekonomi tidak hanya membutuhkan kecerdasan tetapi kreativitas. Selain itu bagi praktisi kampus sosialisasi wakaf ke kampus untuk meningkatkan literasi terhadap wakaf. "Dalam sejarah perkembangan wakaf pada masa kejayaan Islam, wakaf memiliki peranan penting dalam kemajuan peradaban Islam, bahkan kelembagaan wakaf pada masa itu merupakan penentu atas bangkit dan runtuhnya peradaban Islam. Sudah saatnya wakaf kembali berperan dalam pengembangan sistem perekonomian syariah kedepan dan sebagai salah satu instrumen perekonomian nasional".

Keempat, tulisan Fahmi Medias ${ }^{4}$ menjelaskan bahwa salah satu jenis wakaf menurut ijtihad ulama kini adalah wakaf uang memang belum lama dikenal di Indonesia. Walaupun sebenarnya jenis wakaf ini sudah cukup lama dikenal di dunia Islam yakni sejak zaman dinasti Mamluk, para ahli fiqih memperdebatkan boleh atau tidak uang diwakafkan. Ada sebagian ulama membolehkan dan ada yang melarang, namun realitasnya wakaf uang sudah dikenal pada masa imam mazhab, sekarang menjadi concern dan menjadi kajian yang intensif. Di berbagai negara, sudah lama menjadi kajian bahkan sudah diimplementasikan serta diatur dalam perundang-undangan. Problem yang mendasar terjadi adalah terkait pengelolaannya belum dilakukan secara profesional dan nadzir cenderung menjadikan pekerjaan mereka sebagai side job.

3 Muhamad Anis, 'Sarasehan", Wakaf Goes to Campus, Republika, 12/12/2018

${ }^{4}$ Fahmi Medias, Wakaf Produktif dalam Perspektif Ekonomi Islam, La Riba, Vol. IV, No.I, Juli 2010, hal. 78 
Selanjutnya distingsi tulisan ini dengan hasil penelitian dan opini pemerhati manajemen wakaf sebelumnya adalah memfokuskan pada sosialisasi lembaga baik eksistensi maupun program BWI Bangka Belitung dan mendeskripsikan tata kelola dan pemberdayaan dana wakaf sebagai icon baru bagi umat.

\section{Kajian Teori}

\section{a. Pengertian Wakaf}

Ada banyak definisi yang menjelaskan tentang wakaf, antara lain:

Muhammad Jawad Mughniyah mengatakan secara etimologis, istilah wakaf berasal dari tiga kata, yaitu: al-waqf (wakaf), al-habs (menahan), dan at-tasbil (berderma untuk sabilillah). Kata al-waqf adalah bentuk masdar (gerund) dari ungkapan waqfu asy-syai', yang berarti menahan sesuatu. Sedangkan secara terminologis, wakaf adalah sejenis pemberian yang berlaku dengan mempertahankan barang pemberian itu sendiri dan membebaskan pemanfaatannya. Artinya mempertahankan keutuhan barang itu agar tidak diwarisi, tidak dijual, tidak dihibahkan, tidak digadaikan, tidak disewakan, tidak dipinjamkan, dan sebagainya. ${ }^{5}$

Dalam Kamus Bahasa Arab-Melayu, Muhammad Fadlullah dan B. Th. Brondgeet menjelaskan kata-kata wakaf diadopsi dari bahasa Arab al-habsu, dari kata kerja habasa-yahbisu-habsan berarti menjauhkan orang dari sesuatu atau memenjarakan. Kemudian kata ini berkembang menjadi habbasa dan berarti mewakafkan harta karena Allah. Kata wakaf sendiri berasal dari kata kerja waqafa-yaqifu-waqfan yang berarti berhenti atau berdiri Adapun menurut istilah, wakaf berarti berhenti atau menahan harta yang dapat diambil manfaatnya tanpa musnah seketika

${ }^{5}$ Muhammad Jawad Mughniyah, Fiqih Imam Ja'far Shadiq, (Jakarta: Lentera, 2009), 
dan untuk penggunaan yang mubah serta dimaksudkan untuk mendapatkan keridhaan Allah SWT. ${ }^{6}$

Pendapat lain menjelaskan bahwa kata wakaf yang sudah menjadi bahasa Indonesia itu berasal dari kata kerja bahasa Arab waqafa (fi'il madhy), yaqifu (fi'il mudhari), dan (waqfan (isim mashdar) yang secara etimologis (lughah, bahasa) berarti berhenti, berdiri, berdiam di tempat, atau menahan. Kata wakafa dalam bahasa Arab adalah sinonim dari kata hasaba (fi'il madhy), yahbisu (fi'il mudhary), dan habsan (isim mashdar) yang menurut etimologi juga bermakna menahan. Dalam hal ini ada pula yang menarik untuk dicermati dan agar menjadi ingatan bahwa ternyata Rasulullah SAW menggunakan kata al-habs (menahan), yaitu menahan suatu harta benda yang manfaatnya digunakan untuk kebajikan dan dianjurkan agama. ${ }^{7}$

Jadi wakaf adalah perbuatan hukum wakif untuk memisahkan dan/atau menyerahkan sebagian harta benda miliknya untuk dimanfaatkan selamanya atau untuk jangka waktu tertentu sesuai dengan kepentingannya guna keperluan ibadah dan/atau kesejahteraan umum menurut syariah. Wakaf berfungsi mewujudkan potensi dan memanfaatkan secara ekonomis harta benda wakaf untuk kepentingan ibadah dan untuk memajukan kesejahteraan umum. ${ }^{8}$

Oleh sebab itu, perwakafan adalah salah satu ajaran Islam, yang dapat dikategorikan sebagai ibadah amaliyah. ${ }^{9}$ Ibadah ini sangat tinggi nilainya, sebagaimana dikemukakan dalam hadits yang diriwayatkan

\footnotetext{
${ }^{6}$ Machmudah, "Manajemen Wakaf Produktif (Studi Perbandingan di Desa Poncorejo dan Desa Pucangrejo Kecamatan Gemuh Kabupaten Kendal)", Skripsi, Fakultas Ekonomi Dan Bisnis Islam Universitas Islam Negeri Walisongo Semarang Tahun 2015, hal. 26.

7 Suhrawardi K. Lubis, dkk, Wakaf dan Pemberdayaan Umat, (Jakarta: Sinar Grafika, 2010), hal.21.

${ }^{8}$ Machmudah, "Manajemen Wakaf, ...., hal. 1.

9 Direktorat Pengembangan Zakat dan Wakaf, Paradigma Baru Wakaf di Indonesia, (Jakarta: Paradigma Baru, 2005), hal. 1.
} 
oleh Muslim dari Abu Hurairah bahwa wakaf adalah salah satu dari tiga perbuatan yang pahalanya tidak terputus sekalipun wakif (pewakaf) telah meninggal dunia. Begitu besarnya penghargaan terhadap wakaf ini, hingga cukup menarik kaum muslimin untuk berwakaf.

\section{b. Pengertian Wakaf Produktif}

Wakaf produktif berasal dari dua kata yaitu wakaf dan produktif, hal ini dikarenakan benda yang diwakafkan harus didistribusikan dan dimanfaatkan hanyalah hasil dari pokok harta benda wakaf, sedangkan pokoknya masih tetap utuh. Dalam hal ini seorang nadzir dituntut untuk memberdayakan harta benda wakaf agar menghasilkan suatu produk kemudian hasil tersebut didistribusikan kepada mauquf 'alaih. Namun di sisi lain nadzir juga dituntut untuk melestarikan pokok harta benda wakaf tersebut agar tidak berkurang. Oleh karena itu wakaf merupakan kegiatan menyimpan dan berinvestasi secara bersamaan. ${ }^{10}$

Sementara produktif merupakan kata sifat dari produksi yang didefinisikan sebagai kegiatan manusia untuk menghasilkan barang atau jasa yang kemudian dimanfaatkan oleh konsumen. Sedangkan Rustam Effendi mendefinisikan produksi sebagai tindakan dalam membuat komoditi, barang-barang dan jasa. Wakaf produktif adalah memindahkan harta dari upaya konsumtif menuju produktif dan investasi dalam bentuk modal produksi yang dapat memproduksi dan menghasilkan sesuatu sehingga dapat dimanfaatkan pada masa-masa mendatang, baik oleh pribadi, kelompok maupun masyarakat luas. Dengan demikian, wakaf produktif merupakan kegiatan menabung dan berinvestasi secara bersamaan. ${ }^{11}$

${ }^{10}$ Dahwan, Pengelolaan Benda Wakaf Produktif, Jurnal Aplikasi Ilmu-Ilmu Agama, Vol. 9, No.1, Juni 2008, hal. 73.

11 Ibid, 
Menurut Mundzir Qahaf, wakaf produktif yaitu wakaf yang pokok barangnya digunakan untuk kegiatan produksi dan hasilnya diberikan sesuai dengan tujuan wakaf dan harta benda atau pokok tetap yang diwakafkan untuk dipergunakan dalam kegiatan produksi dan hasilnya disalurkan sesuai dengan tujuan wakaf. Keuntungan dari wakaf produktif ini diharapkan dapat mendukung dan membiayai fungsi pelayanan sosial wakaf. Realisasi wakaf produktif antara lain berbentuk sawah, kebun, kolam ikan, pertokoan, apartemen, dan hotel. Penjelasan diatas berarti bahwa benda wakaf yang dipergunakan dalam kegiatan produksi dimanfaatkan oleh penerima wakaf sesuai dengan kesepakatan yang terjadi antara pemberi wakaf dan penerima wakaf. Selain itu benda wakaf tidak dapat dimiliki secara pribadi atau perorangan, tetapi benda wakaf merupakan milik Allah SWT.12

Pada bagian lain, wakaf produktif diartikan sebagai pemberdayaan wakaf yang ditandai dengan tiga ciri utama, pola manajemen yang integratif, mengikuti asas kesejahteraan nazhir, dan asas transparansi dan tanggung jawab. Pola manajemen wakaf integratif berarti memberi peluang bagi dana wakaf untuk dialokasikan kepada program-program pemberdayaaan dengan segala biaya yang tercakup di dalamnya. Asas kesejahteraan nazhir menurut pekerjaan nazhir tidak lagi diposisikan sebagai pekerja sosial, tetapi sebagai seorang profesional yang bisa hidup layak dengan posisi tersebut. Sedangkan asas transparansi dana tanggung jawab mengharuskan lembaga wakaf melaporkan proses pengelolaan dana kepada masyarakat/umat setiap tahun. ${ }^{13}$

Wakaf produktif merupakan untuk kepentingan produksi, baik dalam bidang pertanian, perindustrian, perdagangan, dan jasa yang

\footnotetext{
${ }^{12}$ Machmudah, "Manajemen Wakaf, ...., hal. 49

${ }^{13}$ Dahwan, Pengelolaan Benda, ...., hal. 73.
} 
manfaatnya bukan pada benda secara langsung, tetapi dari keuntungan bersih hasil pengembangan wakaf. Wakaf produktif adalah sebuah skema pengelolaan donasi wakaf dari umat, yaitu dengan memproduktifkan donasi tersebut, hingga mampu menghasilkan surplus yang berkelanjutan. Donasi wakaf dapat berupa benda bergerak, seperti uang dan logam mulia, maupun benda tidak bergerak, seperti tanah dan bangunan. Surplus wakaf produktif inilah yang menjadi sumber dana abadi bagi pembiayaan kebutuhan umat, seperti pembiayaan pendidikan dan pelayanan kesehatan yang berkualitas.

Lebih lanjut program wakaf produktif menjadi inisiatif baru pengembangan wakaf, agar lebih bermanfaat di masyarakat, sebab istilah wakaf produktif merujuk pada skema pengelolaan wakaf. Harta benda yang diwakafkan digunakan dalam kegiatan produksi dan hasilnya disalurkan sesuai dengan tujuan wakaf. Mohammad Nuh mengatakan wakaf produktif telah terbukti mampu menjadi instrumen kesejahteraan, sebab model wakaf produktif bukan hanya sekedar ada aktivitas pengumpulan wakaf, namun juga bermanfaat dan lebih besar lagi bagi umat dan bangsa.

"Kita inginkan bukan sekedar ada, tapi adanya hasil wakaf yang bisa membebaskan kemiskinan, tapi sekaligus sustainable, atau terus menerus bermanfaat untuk jangka panjang. Dan itulah yang membedakan wakaf produktif, dengan zakat dengan infaq," kata M Nuh di forum diskusi ISEF 2018 tentang 'Inovasi Wakaf untuk Kemartabatan dan Kemakmuran Bangsa". ${ }^{14}$

\section{Macam-Macam Wakaf Produktif}

Adapun jenis-jenis wakaf produktif adalah: ${ }^{15}$

${ }^{14}$ Republika, 12/12/2018

${ }^{15}$ Abdrrahman Kasdi, Model Pemberdayaan Wakaf Produktif Di Indonesia, Jurnal Ziswaf, Vol. 1, No.1, Juni 2014, hal. 115-116 
a. Wakaf berupa benda tidak bergerak meliputi: Hak atas tanah sesuai dengan ketentuan peraturan perundang-undangan yang berlaku baik yang sudah maupun yang belum terdaftar; Bangunan atau bagian bangunan yang berdiri di atas tanah sebagaimana dimaksud pada angka 1; Tanaman dan benda lain yang berkaitan dengan tanah; Hak milik atas satuan rumah susun sesuai dengan ketentuan peraturan perundang-undangan yang berlaku.

b. Wakaf berupa benda tidak bergerak lain sesuai dengan ketentuan syari'ah dan peraturan perundang-undangan yang berlaku (UU No. 41 Tahun 2004 tentang Wakaf Pasal 15). Adapun benda bergerak yaitu harta benda yang tidak bisa habis karena dikonsumsi, meliputi: 1) Uang; 2) Logam mulia; 3) Surat berharga; 4) Kendaraan; 5) Hak atas kekayaan intelektual; 6) Hak sewa; dan 7) Benda bergerak lain sesuai dengan ketentuan syari'ah dan peraturan perundang-undangan yang berlaku.(UU No. 41 Tahun 2004 tentang Wakaf pasal 16).

Terdapat beberapa pendapat yang mengklasifikasikan wakaf produktif sebagai berikut:

\section{a) Wakaf Uang}

Wakaf uang dalam bentuknya, dipandang sebagai salah satu solusi yang dapat membuat wakaf menjadi lebih produktif, sebab uang dalam konteks ini tidak lagi dijadikan alat tukar menukar saja. Wakaf uang dipandang dapat memunculkan suatu hasil yang lebih banyak. Mazhab Hanafi dan Maliki mengemukakan tentang kebolehan wakaf uang, sebagaimana yang disebut Al-Mawardi : “Abu Tsaur meriwayatkan dari Imam Syafi'i tentang kebolehan wakaf dinar dan dirham". Dari Wahbah Az-Zuhaily, dalam kitab Al-figh Islamy Wa Adilatuhu menyebutkan bahwa mazhab Hanafi membolehkan wakaf uang karena uang yang menjadi modal usaha itu, dapat bertahan lama dan banyak manfaatnya untuk kemaslahatan umat. 
Bahkan MUI juga telah mengeluarkan fatwa tentang wakaf tunai sebagai berikut :

(a) Wakaf uang (cash wakaf/waqf al-nuqut) adalah wakaf yang dilakukan oleh sekelompok atau seseorang maupun badan hukum yang berbentuk wakaf tunai.

(b) Termasuk dalam pengertian uang adalah surat-surat berharga.

(c) Wakaf yang hukumnya jawaz (boleh)

(d) Wakaf yang hanya boleh disalurkan dan digunakan untuk hal-hal yang dibolehkan secara syar'i

(e) Nilai pokok wakaf yang harus dijamin kelestariannya, tidak boleh dijual, dihibahkan atau diwariskan.

Selain Fatwa MUI diatas, pemerintah melalui DPR juga telah mengesahkan Undang-undang No 41 tahun 2004 tentang Wakaf, yang didalamnya juga mengatur bolehnya wakaf berupa uang. Pelaksanaan wakaf uang, dijelaskan dalam Abdurrahman Kasdi pasal 23 menjelaskan bahwa wakif dapat mewakafkan benda bergerak berupa uang melalui LKS yang ditunjuk oleh Menteri sebagai LKS penerima wakaf uang (LKS-PWU). Sampai saat ini, sudah ada 5 LKS-PWU yang diresmikan oleh Menteri Agama sebagai konsekuensi dari Peraturan Menteri Agama Nomor 4 Tahun 2009 tentang Administrasi Pendaftaran Wakaf Uang yang ditandatangani pada tanggal 29 Juli 2009, yakni Bank Mega Syariah, Bank Syariah Mandiri, Bank BNI Syariah, Bank DKI Syariah, dan Bank Muamalat. Mungkin pada tahun berikutnya akan bertambah LKS-PWU yang diperkenankan untuk menerima wakaf uang. (UU No. 41 Tahun 2004 tentang Wakaf Pasal 8). 16

\footnotetext{
${ }^{16}$ Ibid.,
} 
Adapun benda bergerak berupa uang dijelaskan dalam pasal 22 dan 23 Peraturan Pemerintah Nomor 42 Tahun 2006 Tentang Pelaksanaan Undang-Undang Nomor 41 Tahun 2004 Tentang Wakaf. Pasal 22 menjelaskan bahwa: wakaf uang yang dapat diwakafkan adalah mata uang rupiah; dalam hal uang yang akan diwakafkan masih dalam mata uang asing, maka harus dikonversi terlebih dahulu ke dalam rupiah. ${ }^{17}$

Selanjutnya pemerintah menyatakan bahwa pengelolaan wakaf uang melalui lembaga keuangan syariah ini atas dasar pertimbangan keuangan. Ada dua hal yang dicermati dari penyerahan dan pengelolaan wakaf tunai oleh lembaga keuangan syariah, (1) lembaga keuangan syariah adalah lembaga profit dan komersial, ia juga harus memikirkan pendayagunaan sosial wakaf, namun tidak boleh semata-mata dana wakaf hanya concern pada kegiatan komersialnya sendiri, sehingga wakaf itu harus diberikan manfaat ekonomi bagi umat, dan (2) tereduksinya peran dan pemberdayaan masyarakat dalam hal-hal produktif, sementara intinya adalah kapabilitas, kredibilitas, profesionalitas dari nadzir. ${ }^{18}$ Salah satu model yang dapat dikembangkan dalam mobilisasi wakaf uang adalah model Dana Abadi, yaitu dana yang terhimpun dari berbagai sumber dengan berbagai cara yang ah dan halal. Kemudian dana yang terhimpun dengan volume besar diinvestasikan dengan tingkat keamanan yang tinggi melalui Lembaga Penjamin Syariah (LPS). Keamanan investasi ini paling tidak mencakup dua aspek: pertama, keamanan nilai pokok dana abadi, sehingga tidak terjadi penyusutan (adanya jaminan keutuhan). Sedangkan kedua, investasi dana tersebut

\section{${ }^{17}$ Ibid., \\ ${ }^{18}$ Ibid.,}


bisa diproduktifkan dan mampu mendatangkan hasil atau pendapatan (incoming generating allocation). ${ }^{19}$

\section{b) Wakaf Uang Tunai}

Secara umum definisi wakaf tunai adalah penyerahan asset wakaf berupa uang tunai yang tidak dapat dipindah tangankan dan dibekukan selain untuk kepentingan umum yang tidak mengurangi jumlah pokoknya. Di Indonesia wakaf uang tunai relatif baru dikenal. Wakaf uang tunai adalah objek wakaf selain tanah maupun bangunan yang merupakan harta tak bergerak. Wakaf dalam bentuk uang tunai dibolehkan, dan dalam prakteknya sudah dilaksanakan oleh umat Islam. 11

Adapun manfaat wakaf uang tunai antara lain:

(a) Seseorang yang memiliki dana terbatas sudah bisa mulai memberikan dana wakafnya tanpa harus menunggu menjadi tuan tanah terlebih dahulu.

(b) Melalui wakaf uang, asset-asset berupa tanah-tanah kosong bisa mulai

dimanfaatkan dengan sarana yang lebih produktif untuk kepentingan umat.

(c) Dana wakaf tunai juga bisa membantu sebagian lembagalembaga pendidikan Islam.

\section{c) Wakaf Saham}

Saham sebagai barang yang bergerak juga dipandang mampu menstimulasi produk-produk yang dapat didedikasikan untuk umat, bahkan dengan modal yang besar, saham malah

\section{${ }^{19}$ Ibid.,}


justru akan memberi kontribusi yang cukup besar dibandingkan jenis perdagangan yang lain.

d) Sertifikat Wakaf Tunai

Sertifikat wakaf tunai adalah salah satu instrumen yang sangat potensial dan menjanjikan dan dapat dipakai untuk menghimpun dana umat dalam jumlah besar. Sertifikat wakaf tunai merupakan semacam dana abadi yang diberikan oleh individu maupun lembaga muslim yang dengan keuntungan dana tersebut akan digunakan untuk kesejahteraan masyarakat.

\section{c. Landasan Syariah Tentang Wakaf}

1. Al-Qur'an

a. QS. Al Hajj :77. Artinya: "Hai orang-orang yang beriman, ruku'lah kamu, sujudlah kamu, sembahlah Tuhanmu dan perbuatlah kebajikan, supaya kamu mendapat kemenangan".

b. QS. Ali Imran: 92. Artinya: "Kamu sekali-kali tidak sampai kepada kebajikan (yang sempurna), sebelum kamu menafkahkan sehahagian harta yang kamu cintai. dan apa saja yang kamu nafkahkan Maka Sesungguhnya Allah mengetahuinya".

c. QS. Al Baqarah: 3. Artinya: “(yaitu) mereka yang beriman kepada yang ghaib, yang mendirikan shalat, dan menafkahkan sebahagian rezki yang Kami anugerahkan kepada mereka".

2. Hadist

Dari Abu Hurairah . a bahwasanya Rosulullah bersabda: “Apabila manusia meninggal dunia, putuslah semua amalnya, kecuali tiga macam amal:sedekah jariyah (wakaf), ilmu yang bermanfaat dan anak yang soleh selalu mendakan orang tuanya".

3. Hukum Positif
a. Undang-undang No. 41 Tahun 2004 Tentang Wakaf.
b. Undang-undang Pokok Agraria.
c. Peraturan Pemerintahan No. 42 Tahun 2006. 
d. Inpres No. 1 Tahun 1991 Tentang Kompilasi Hukum Islam $(\mathrm{KHI}) \cdot{ }^{20}$

\section{d. Potensi dan Peta Wakaf Produktif Di Indonesia}

Salah satu upaya strategis yang dilakukan oleh pemerintah untuk mengembangkan lembaga wakaf dan memberdayakan potensinya sehingga memberikan dampak yang positif dalam perbaikan kehidupan sosial dan ekonomi umat Islam. Sebagai langkah yang sangat tepat, untuk wakaf produktif maka perlu dikembangkan suatu sistem pengelolaan dan pengembangan wakaf dengan berbagai model dan manajerial dalam perspektif usaha untuk memajukan umat, bangsa dan negara Indonesia.

Adapun macam-macam model upaya peningkatan kesejahteraan kehidupan ekonomi masyarakat yaitu $:^{21}$

1) Model Wakaf Produktif Pembangunan Gedung

Kementerian Agama memiliki kewenangan untuk mendorong kegiatan umat Islam dalam mengembangkan wakaf produktif, kegiatan percontohan dalam pengembangan wakaf secara produktif antara lain:

a) Pertokoan, bangunan dari gedung pertokoan tersebut akan difungsikan secara produktif dengan cara disewakan/dikontrakkan ke berbagai pihak yang membutuhkan. Bangunan pertokoan yang dikelola secara produktif dan profesional akan menghasilkan keuntungan yang kemudian dapat disalurkan untuk pemberdayaan kehidupan misalnya dengan cara pemberian beasiswa pendidikan maupun kredit mikro pada anak yatim dan fakir miskin.

20 Direktorat Pemberdayaan Wakaf, Panduan Pemberdayaan Tanah Wakaf Produktif Strategi di Indonesia, 2008, hlm. 20-34.

21 Muhibbin, Paradigma Baru Pengelolaan dan Pemberdayaan Wakaf Produktif di Indonesia, (online) available: www.rumahwakaf.org. Diakses pada tanggal 10 Desember 2018. 
b) Gedung Wakaf dan Bisnis Center; Idealnya wakaf di Indonesia yang sudah bersertifikat diberdayakan agar lebih produktif dan bermanfaat bagi masyarakat muslim. Contohnya mendirikan gedung wakaf dan gedung pusat bisnis untuk menfasilitasi berbagai pengelolaan harta wakaf secara profesional dan bertanggung jawab. Dengan membangun gedung bisnis center, maka berbagai bidang usaha strategis bisa dilakukan, seperti pembukaan showroom, warung net, foto copy, restoran, kantor pelayanan haji dan umrah, travel dan perjalanan wisata, dan lain sebagainya.

c) Rumah Kost Muslim, atau tempat tinggal sementara bagi pekerja dan anak didik merupakan sesuatu yang lazim, bahkan salah satu kebutuhan dasar bagi siapapun yang ingin mengembangkan kualitas kehidupannya dan sebagian mahasiswa tidak jarang yang mencari rumah kost yang dan tidak dicampuri oleh pemiliknya. Dengan memanfaatkan dana bantuan pemberdayaan wakaf produktif dan pengelolaan yang baik, dapat mencapai pendapatan rumah kost yang disewakan tersebut sehingga dapat disalurkan untuk pemberdayaan umat.

d) Mini Market, salah satu upaya yang dilakukan untuk menutupi kekosongan adalah melalui wakaf produktif dengan membuat mini market yang lebih bertujuan sosial, bukan hanya untuk keuntungan ekonomi semata. Keberadaan mini market akan memberikan dampak positif bagi masyarakat sekitar.

2) Model Wakaf Produktif Pengembangan Usaha

Indonesia sangat terkenal sebagai Negara yang memiliki dua potensi sumber daya alam yang besar, yaitu sektor darat agrobisnis dan sektor kelautan. Adapun beberapa yang dapat diberdayakan dalam model ini khususnya di sektor agrobisnis dan kelautan yaitu 
peternakan, perikanan, perkebunan, industri rumahan, perbengkelan, dll.

3) Model Pengeloaan Cash Wakaf Untuk Mensejahterakan Rakyat

Wakaf tunai sangat tepat memberikan jawaban yang menjanjikan dalam mewujudkan kesejahteraan sosial dan membantu mengatasi krisis ekonomi Indonesia. Dalam perkembangan wakaf produktif kekinian di Indonesia, wacana wakaf tunai telah menjelma nyata dalam implementasi produk-produk funding lembaga keuangan syariah dan lembaga amil zakat seperti wakaf tunai dompet dhuafa republik dan waqtumu (wakaf tunai muamalat) yang diluncurkan Baitul Maal Muamalat-BMI.

Selanjutnya apabila para pengelola atau para nadzir harta benda wakaf telah memenuhi standar kualifikasi, maka pengelolaan harta wakaf tentu akan berkembang dengan baik. Pemberdayaan harta wakaf tersebut dapat dilakukan dengan baik dan maksimal sebagaimana diharapkan bersama. Pemberdayaan harta wakaf tersebut dapat dilakukan dengan mengupayakannya sehigga harta wakaf dapat dijadikan sebagai:22

a. Aset yang menghasilkan produk barang atau jasa. Tentu ini memerlukan perencanaan yang matang, bentuk dan kemungkinan pengembangan serta tantangan dan hambatannya.

b. Aset yang berbentuk investasi usaha. Artinya ketika pengelola telah dapat mengumpulkan keuntungan pengelolaan harta wakaf, maka keuntungan yang berupa uang tersebut dapat di investasikan dalam bentuk musyarakah maupun mudharabah kepada lembaga keuangan syariah yang kredibel maupun pengusaha dan pihak-pihak lain yang amanah dan profesional.

\section{${ }^{22}$ Ibid.,}


Dalam mengoptimalkan pengembangan pemberdayaan harta wakaf, maka perlu adanya strategi agar dapat lebih maksimal lagi. Strategi tersebut dapat berupa:

\section{Kemitraan}

Nazhir harus menjalin kerjasama dengan pihak lain yang mempunyai modal dan ketertarikan usaha sesuai dengan posisi tanah strategis yang ada dengan nilai komersialnya cukup tinggi. Jalinan kerjasama ini pun harus sesuai dengan syariah sehingga daapat menggerakkan dan berkontribusi terhadap perekonomian Islam. Pihak-pihak ketiganya yaitu: ${ }^{23}$

a. Lembaga investasi usaha yang berbentuk badan usaha non lembaga jasa keuangan.

b. Investasi perseorangan yang memiliki modal cukup. Modal yang diinvestasikan dalam bentuk saham kepemilikan sesuai dengan kadar yang ada.

c. Lembaga perbankan syariah atau lembaga keungan syariah lainnya sebagai pihak yang memiliki dana pinjaman.

d. Lembaga perbankan internasional yang cukup peduli dengan pengembangan tanah wakaf di Indonesia seperti Islamic Development Bank (IDB).

e. Lembaga keuangan dengan sistem pembangunan BOT (Built of Transfer).

f. Lembaga penjamin syariah sebagai pihak yang akan menjadi sandaran nazhir apabila upaya pemberdayaan tanah wakaf mengalami kerugian.

23 M. Ichsan Amir Mujahid, Strategi Nazhir dalam Pengembangan Wakaf Produktif, (online) evailable: www.indahnyaberbagi.web.id, di akses pada tanggal 10 Desember 2018. 
g. Lembaga Swadaya Masyarakat (LSM) yang peduli terhadap pemberdayaan ekonomi umat, baik dalam atau luar negeri.

Selain bekerjasama dengan lembaga yang dijelaskan di atas, nazhir juga dapat melakukan kerjasama dengan pihak-pihak lain. Seorang nazhir juga harus memiliki sinergi atas program-program usahanya dengan Majelis Ulama Indonesia (MUI), perguruan tinggi, lembaga konsultan keuangan atau lembaga-lembaga lainnya.

2. Terbentuknya Undang-Undang Wakaf dan Badan Wakaf Indonesia

Tersedianya payung hukum UU RI No. 41 Tahun 2004 tentang wakaf dan Peraturan Pemerintah No. 42 Tahun 2006 tentang pelaksanaannya yang membuka peluang jenis harta yang boleh diwakaf tidak terbatas benda tidak bergerak berupa tanah tetapi juga meliputi wakaf benda yang bergerak yang meliputi uang dan benda berharga lainnya. Badan Wakaf Indonesia merupakan lembaga yang independen dan mempunyai peran strategis, diharapkan dapat membantu, baik dalam pembiayaan, pembinaan maupun pengawasan dan peningkatan kulitas nazhir dapat melakukan pengelolaan wakaf secara produktif.

Untuk itu, perlu dibentuk ekosistem wakaf produktif, jika ekosistemnya sudah terbangun maka, orang mewakafkan hartanya tidak membutuhkan energi yang besar. Termasuk BWI menekankan perlunya membangun literasi perwakafan, untuk melaksanakan wakaf produktif. Elemen lain yang tidak kalah penting mewujudkan wakaf produktif adalah saling sinergi antar lembaga wakaf. Seperti ungkapan M. Nuh selaku Wakil Ketua BWI:

"Perlu saling bantu project wakaf yang bersama, termasuk perbankan syariah ikut berbondong bondong dengan nazhir (pihak penerima harta) wakaf, agar harkat dan martabat bangsa bisa bangkit," katanya. Ke depan, BWI 
berharap dengan wakaf produktif, umat Islam bisa berkontribusi lebih nyata pada pembangunan ekonomi nasional. Membangun Jalan tol, rumah sakit-rumah sakit, pabrik hingga pelabuhan yang dibangun oleh wakaf. Sehingga wakaf ini menjadi oksigen, yang terus masuk mendukung pembangunan di Indonesia".

Lebih lanjut peran Bank Indonesia harus ikut mendorong upaya pemanfaatan wakaf secara produktif yang sesuai dengan Fatwa Dewan Syariah Nasional-MUI. Wakaf produktif dianggap mampu menjadi salah satu solusi instrumen pelengkap pembiayaan pembangunan. Deputi Gubernur BI Erwin Rijanto ${ }^{24}$ mengatakan:

"Pengembangan wakaf produktif dibutuhkan untuk mendorong perekonomian nasional, khususnya di tengah masih terbatasnya pembiayaan sosial atau Islamic social finance. Untuk itulah, kata dia, BI telah menyusun dan menerbitkan waqf core principles (WCP) dan penerbitan waqf-linked sukuk (WLS). Wakaf linked sukuk ini merupakan wakaf tunai, yang akan dibelikan Surat Berharga Syariah Negara (SBSN). Instrumen itu merupakan alternatif berinvestasi sekaligus untuk beramal.

Erwin Rijanto menjelaskan wakaf linked sukuk merupakan hasil kerja sama antara BI, BWI dan Kemenkeu. Dengan inovasi ini, diharapkan pengembangan wakaf secara masif dapat dicapai sehingga pembangunan ekonomi syariah bisa dipercepat, serta memperkuat stabilitas sistem keuangan nasional. Dalam rangka mempertahankan dan melanjutkan program pengembangan wakaf, secara implementasi Bank Indonesia bekerja sama dengan Universitas Darussalam Gontor mendirikan pusat pendidikan bidang wakaf Internasional Center of Awqaf Studies (ICAST).

Manajemen wakaf memberikan pembinaan dan pelayanan terhadap sejumlah harta yang dikhususkan untuk merealisasikn

${ }^{24}$ Republika, 12 Desember 2018 
tujuan tertentu. Karena itu, usahanya harus terkonsentrasi pada upaya merealisasikan sebesar mungkin perolehan manfaat untuk tujuan yang telah ditentukan pada harta tersebut. Untuk itu target manajemen wakaf produktif dapat disimpulkan sebagai berikut:

1. Meningkatkan kelayakan produksi harta wakaf sehingga mencapai target ideal untuk memberi manfaat sebesar mungkin bagi tujuan wakaf

2. Melindungi pokok-pokok harta wakaf dengan mengadakan pemeliharaan dan penjagaan yang baik dalam meginvestasikan harta wakaf dan meminimalisir risiko investasi. Sebab harta wakaf merupakan sumber dana abadi yang hasilnya disalurkan untuk berbagai tujuan kebaikan

3. Melaksanakan tugas distribusi hasil wakaf dengan baik kepada tujuan wakaf yang ditentukan baik berdasarkan pernyataan wakif dalam akte wakaf maupun berdasarkan pendapat fikih dalam kondisi wakaf hilang aktenya dan tidak diketahui tujuannya, mengurangi kemungkinan adanya penyimpangan dala menyalurkan hasil-hasil tersebut.

4. Berpegang teguh pada syarat-syarat wakif baik yang berkenan dengan jenis investasi dan tujuannya maupun dengan tujuan wakaf

5. Memberikan penjelasan kepada para dermawan dan mendorong mereka untuk melakukan wakaf baru dan secara umum memberi penyuluhan serta menyarankan pembentukan wakaf baru baik secara lisan maupun tulisan dengan cara memberi keteladanan. 
Oleh sebab itu pengurus wakaf memerlukan pengawasan ketat, sehingga pola ini dapat mengganti bagian yang hilang antara manfaat manajer dengan kemaslahatan wakaf. Terdapat beberapa model pengawasan yaitu pengawasan manajerial berarti manajemen pengelolaan menempati posisi paling strategis dalam pengembangan wakaf produktif. Jenis pengawasan ini membutuhkan kualitas kepemimpinan dalam lembaga wakaf agar lebih transparan, aspiratif dan bertanggungjawab. ${ }^{25}$

\section{d. Upaya Sosialisasi Lembaga dan Program BWI Bangka Belitung; Paradigma baru Wakaf Produktif}

1. Sejarah BWI Bangka Belitung

Adapun dasar hukum berdirinya BWI adalah UU Nomor 4/41/2004, Pasal 47. Selanjutnya BWI Bangka Belitung didirikan pada tanggal 29 Januari 2019 dengan tujuan memajukan dan mengembangkan perwakafan di Indonesia khususnya di Bangka Belitung. Adapun tugas dan wewenang BWI secara umum adalah melakukan pembinaan terhadap nadzir; pengelolaan dan pengembangan harta benda wakaf; memberikan persetujuan dan izin atas perubahan peruntukan atas harta benda wakaf dan mengangkat, memberhentikan dan mengganti nadzir.

2. Program Kerja Badan Wakaf Indonesia Bangka Belitung

Ada beberapa program kerja yang dicanangkan oleh BWI Bangka Belitung antara lain:26

\section{1) Program Edukasi tentang Wakaf}

\footnotetext{
${ }^{25}$ Abdul Hakim, Manajemen Harta Wakaf Produktif dan Investasi dalam Sistem Ekonomi Syariah, Jurnal Riptek, Vol. 4, Nomor II, Tahun 2010, hlm 27

${ }^{26}$ Dokumentasi Badan Wakaf Indonesia Bangka Belitung, Tahun 2019
} 
Implementasi program ini dilakukan dengan cara sosialisasi kepada masyarakat terkait regulasi dan inovasi wakaf kekinian dengan bentuk wakaf produktif sesuai Undang-Undang RI Nomor 41 Tahun 2004 dan termasuk pembinaan terhadap nadzir. Program ini dilakukan mengingat saat ini mind set masyarakat "menganggap" wakaf masih identik dengan wakaf tanah atau wakaf tiga atau empat $\mathrm{M}$ yaitu wakaf berupa masjid, mushalla, madrasah dan makam. Padahal jika hanya mengacu pada empat $M$ tersebut tidak dapat dikembangkan pada usaha-usaha produktif. Oleh sebab itu program edukasi/sosialisasi ini dapat disebut dengan "Program Memasyarakatkan Wakaf Untuk Masyarakat".

\section{2) Program Pendataan Harta/Aset Wakaf; Validasi Data Tanah Wakaf dan Wakaf di Bangka Belitung.}

Program ini dilakukan dengan cara menghimpun, memvalidasi dan menginventarisir serta melakukan mapping data dan asset-aset wakaf lainnya yang ada di Kabupaten dan Kota di Bangka Belitung. Hal ini dilakukan mengingat masih ada tanah wakaf yang belum diinventarisir dan belum dibuat sertifikat atas tanah wakaf tersebut. Kondisi ini disebabkan:

a. Tanah yang diwakafkan oleh masyarakat, namun secara administratif belum didokumentasikan baik di Kantor Kementerian Agama Kabupaten/Kota/Wilayah. Namun kesadaran masyarakat untuk mewakafkan tanahnya patut diapresiasi, sehingga kedepannya potensi ini harus terus ditingkatkan tingkat partisipasinya

b. Tidak terdokumentasinya tanah yang diwakafkan oleh masyarakat baik oleh BWI maupun Kementerian Agama, dikarenakan minimnya pengetahuan masyarakat tentang adanya Administrasi Perwakafan (seperti pengadaan sertifikat tanah wakaf). Oleh sebab itu eksistensi 
dan peran aktif BWI diharapkan guna memberikan pemahaman bagi masyarakat agar asset yang diwakafkan didokumentasikan.

\section{3) Program Pengumpulan Aset Wakaf (Wakaf Uang)}

Program ini dilakukan dengan cara mengumpulkan asset wakaf berupa uang dari wakif (orang yang memberikan wakaf) melalui:

a. Ada sosialisasi bahwa masyarakat berwakaf untuk masyarakat; bahwa harta/asset wakaf dalam berbagai bentuk: ibadah, pendidikan, perekonomian, kesehatan dan kepentingan lainnya seerti take over kredit dari bank konvensional dan hal-hal yang tidak bertentangan dengan prinsip syariah.

b. Adanya program Wakaf Sahabat; sasarannya adalah pelajar dan mahasiswa. Programnya dinamakan Siswa Wakaf Untuk Siswa (SWS) dan Mahasiiswa Wakaf Untuk Mahasiswa (MWM). Pelaksanaan program ini sebagai upaya BWI Bangka Belitung dalam memperkenalkan dan memasyarakatkan wakaf bagi kaum milenial. Adapun teknisnya BWI/nadzir mengumpul dan mengelola dana wakaf selanjutnya dimanfaatkan bagi pendidikan siswa/mahasiswa yang membutuhkan, sehingga jenis wakaf ini disebut wakaf filantropi (saling membantu).

\section{4) Program Pengelolaan dan Pemberdayaan Aset Wakaf}

Secara implementatif, BWI melakukan komunikasi lintas sektoral untuk menjalin kerjasama dengan stakeholder, termasuk menjajaki program kerjasama yang melibatkan pihak perbankan dan lembaga keuangan syariah. Program ini dilakukan guna meningkatkan kemaslahatan umat; termasuk kemungkinan membangun kerjasama dengan Islamic Development Bank. Lebih jauh upaya pengembangan wakaf produktif dapat dilakukan seperti mendirikan Mart Syariah, 
hotel syariah, rumah sakit Islam dan mendesain produk dan wisata halal.

Mengingat urgennya potensi wakaf sebagai salah satu instrumen dalam upaya memitigasi kemiskinan di Indonesia, khususnya di Bangka Belitung, maka diperlukan strategi dalam pengumpulan, pengelolaan/pendistribusiannya agar mampu berfungsi maksimal. Lebih jauh untuk konteks di Bangka Belitung, eksistensi BWI masih pada tataran sosialisasi program kepada masyarakat, namun apresiasi terkait upaya mengenalkan wakaf produktif sebagai paradigma baru dalam pengelolaan dan pemberdayaan wakaf produktif. Lebih jauh hasil wawancara dengan Bapak Abdul Ghofar selaku Ketua BWI Bangka Belitung mengatakan:

“Keberadaan BWI Bangka Belitung merupakan lembaga baru namun diharapkan dapat memberikan warna baru guna membangun kesadaran masyarakat untuk berwakaf dan memaksimalkan pemberdayaan wakaf produktif untuk usaha-usaha yang mendukung upaya pengentasan kemiskinan dan menghidupkan ekonomi masyarakat".

\section{e. PENUTUP}

Pemberdayaan wakaf produktif memiliki dimensi sosial, artinya eksistensinya tidak hanya mengabdikan diri pada kemaslahatan umat Islam, atau berdimensi teologis-ketuhanan saja, namun harus diorientasikan guna meningkatkan kesejahteraan masyarakat. Selanjutnya perkembangan manajemen wakaf selama beberapa tahun tidak diragukan lagi, secara keseluruhan merupakan upaya perbaikan yang bertujuan memperbaiki manajemen wakaf. Upaya perbaikan ini pada hakekatnya merupakan perubahan pada bentuk dan sistem kepengurusan baru yang sesuai dengan karakteristik wakaf Islam. Hal 
ini sebagai bagian dari lembaga ekonomi erat kaittannya dengan pembangunan masyarakat dan bukan pemerintah. Oleh karena itu, untuk menentukan bentuk manajemen yang diinginkan bagi wakaf sehingga para pengurus wakaf dapat diperkirakan dan direalisasikan.

Adapun konteks pengembangan BWI dan sosialisasi programprogram kepada masyarakat mutlak dilakukan, sehingga masyarakat memiliki "awareness" guna menunaikan wakaf, khususnya wakaf produktif sebagai salah satu instrument lembaga keuangan syariah. Hasil akhirnya diharapkan pemanfaatan aset-aset wakaf untuk usahausaha produktif dapat dilakukan oleh BWI Bangka Belitung. 


\section{DAFTAR PUSTAKA}

Anis. Muhamad. 2018. 'Sarasehan', Wakaf Goes to Campus, Republika, 12 Desember 2018

Dahwan. 2008. Pengelolaan Benda Wakaf Produktif, Jurnal Aplikasi Ilmu-Ilmu Agama, Vol. 9, No.1, Juni 2008

Departemen Agama RI. 2006. Pedoman Pengelolaan \& Pengembangan Wakaf. Jakarta: Direktorat Jendral Bimbingan Masyarakat Islam Direktorat Pemberdayaan Wakaf.

Direktorat Pemberdayaan Wakaf. 2008. Panduan Pemberdayaan Tanah Wakaf Produktif Strategi di Indonesia.

Direktorat Pengembangan Zakat dan Wakaf; Paradigma Baru Wakaf di Indonesia, Jakarta: Paradigma Baru, 2005

Hakim, Abdul. 2010. Manajemen Harta Wakaf Produktif dan Investasi dalam Sistem Ekonomi Syariah, Jurnal Riptek, Vol. 4, Nomor II, Tahun 2010

Ichsan, Muhammad dkk. 2018. Strategi Nazhir dalam Pengembangan Wakaf Produktif, (online) evailable: www.indahnyaberbagi.web.id, di akses pada tanggal 10 Desember 2018.

Kasdi, Abdurrahman. 2014. Model Pemberdayaan Wakaf Produktif Di Indonesia, ZISWAF, Vol. 1, No. 1 Juni 2014

Machmudah, "Manajemen Wakaf Produktif (Studi Perbandingan di Desa Poncorejo dan Desa Pucangrejo Kecamatan Gemuh Kabupaten Kendal)", Skripsi, Fakultas Ekonomi Dan Bisnis Islam Universitas Islam Negeri Walisongo Semarang Tahun 2015

Medias. Fahmi. 2010. Wakaf Produktif dalam Perspektif Ekonomi Islam, La Riba, Vol. IV, No.I, Juli 2010

Muhibbin, Paradigma Baru Pengelolaan dan Pemberdayaan Wakaf Produktif di Indonesia, (online) available: www.rumahwakaf.org. Diakses pada tanggal 10 Desember 2018. 
Paradigma baru pengembangan wakaf produktif

Mughniyah. Muhammad Jawad. 2009. Fiqih Imam Ja'far Shadiq, (Jakarta: Lentera, 2009)

Muhibbin, Paradigma Baru Pengelolaan dan Pemberdayaan Wakaf Produktif di Indonesia, (online) available: www.rumahwakaf.org. Diakses pada tanggal 10 Desember 2018.

Republika, 12 Desember 2018 